\title{
Successful intelligence and giftedness: an empirical study
}

\author{
Mercedes Ferrando ${ }^{1}$, Carmen Ferrándiz ${ }^{1}$, Laura Llor $^{2}$ and Marta Sainz ${ }^{2}$ \\ ${ }^{1}$ Department of Development and Educational Psychology. Murcia University (Spain). \\ ${ }^{2} U C A M$ University (Spain).
}

\begin{abstract}
Título: Inteligencia Exitosa y Superdotación: un estudio empírico.
Resumen: Ahondar en el estudio de la alta habilidad es importante para conocer los distintos tipos de superdotación y talento y poder ofrecer una mejor atención a nuestros alumnos. Existen pocos trabajos empíricos que traten de buscar los perfiles de alta habilidad que se dan en la realidad, más allá del nivel teórico. El presente trabajo trata de identificar los patrones de combinación de las habilidades de inteligencia triárquica definidas por Sternberg en alumnos superdotados. Han participado un total de 431 chicos y chicas de distintos centros de la Región de Murcia. Estos alumnos completaron las tareas de la Batería Aurora (Chart, Grigorenko \& Sternberg, 2008), diseñada para medir la inteligencia analítica, práctica y creativa. De ellos se seleccionaron a los superdotados analíticos $(n=27)$ a los superdotados prácticos $(n=33)$ y a los superdotados creativos $(n=34)$, tomando como criterio que su puntuación en dichas inteligencias fuera mayor de CI 120. Se realizaron diferentes Q-factor análisis sobre los tres grupos de alumnos, de forma que los alumnos se agruparon según sus semejanzas. En total se extrajeron 10 perfiles que muestran cómo se combinan las habilidades de la inteligencia triárquica y que han permitido corroborar la teoría propuesta por Sternberg (2000): el perfil del talento analítico; el perfil práctico, el perfil creativo; el perfil analítico-práctico, el perfil analítico-creativo; el perfil practico-creativo y el perfil de equilibrio sumo.

Palabras clave: Superdotación, Inteligencia exitosa, Perfil cognitivo; Qfactor análisis; Batería Aurora.
\end{abstract}

\begin{abstract}
The aim of our research is to look into the diversity within gifted and talented students. This is important to better understand their complexity and thus offer a more appropriate educational programs. There are rather few empirical works which attempt to identify high abilities profiles (giftedness and talent) that actually exist beyond the theoretical level. The present work intends to single out the different patterns or profiles resulting from the combination of the successful intelligence abilities (analytical, synthetic and practical), as defined by Stenberg. A total of 431 students from the Region of Murcia participated in this study. These students performed the Aurora Battery tasks (Chart, Grigorenko, \& Sternberg, 2008), designed to measure the analytical, practical and creative intelligence. Analytically gifted students $(n=27)$, practically gifted $(n=33)$ and creatively gifted $(n=34)$ were identified, taking as criteria scores equal to or higher than 120 IQ on each intelligence. Different Q-factor analyses were carried out for the three groups of students, in such a way that students were grouped according to their similarities. A total of 10 profiles showing how successful intelligence abilities are combined were obtained, something that has made possible to support the theory put forward by Sternberg (2000): the analytical, practical and creative talent profiles, as well as the resulting combinations, the analytical-practical, analytical-creative, practical-creative profiles, along with the consummate balance talent (high performance in the three types of intelligence).

Keywords: giftedness, successful intelligence, Cognitive profile, Q-factor analysis, Aurora Battery.
\end{abstract}

\section{Introduction}

The aim of our research is to look into the diversity within gifted and talented students. This is important to better understand their complexity and thus offer more appropriate educational programs. While all the highly able individuals are usually grouped together as a homogeneous group, and researchers try to find their common characteristics (e.g. their common personality traits: Sak, 2004); it is true that giftedness and talent tend to be manifested differently in each person (Hernández-Torrano, Ferrándiz, Prieto, Sáinz, Ferrando, \& Bermejo, 2011; Sternberg, 2000). The most usual classifications of talent consider mainly the area of expertise. Thus from traditional approaches, it is assumed that the different types of talent (e.g.: painting, literature, mathematics...) are determined by the interest that each area sparks in the individual, as well as their performance in it (Gardner, 1983/1995; Marland, 1972); such performance usually is acquired through a process of education training and deliberate practice (Ericsson, 2006; Gagné 2015).Other proposals on the classification of talent pay more attention to the cognitive abilities that compose the giftedness profiles. This way, in Renzulli's model (2003), two main types of gifted students are differentiated: the school-house gifted and

* Dirección para correspondencia [Correspondence address]: Mercedes Ferrando. Facultad de Educación, Universidad de Murcia, Campus de Espinardo. 30100. Murcia (Spain). E-mail: mferran@um.es the innovative giftedness, distinguishing between those students who excel at academic tasks and get good grades and those who stand out in creative areas.

Within the widespread idea which claims that cognitive skills are specific and relatively independent from each other, a notion which stems from Gardner's multiple intelligence theory $(1983 / 1989)$, it is accepted that talent can be different, not only for the area in which it aims to specialize, but for the singular combination of cognitive resources. This way, an IQ of 120 (the traditional "IQ" in a general intelligence test) does not offer much information about the type of talent that such a figure conceals, be it verbal talent or mathematical talent, for instance. The key aspect is, then, not measuring the "quantity" of talent, but rather identifying the cognitive profiles of such a talent. The work of Prieto, Ferrándiz and Ballester (2001), attempted to analyze those singular profiles of multiple intelligences existing among students; to do so, 16 primary Education pupils were tested using the assessment tasks of multiple intelligence proposed by the Spectrum project (Gardner, Feldman, \& Krechevsky, 1998). The different profiles were qualitative analyzed looking for differences, proving that not all students present the same cognitive profile of strengs and weakness.

Taking into account the different combinations of cognitive abilities, Castelló (Castelló \& Batlle, 1998) suggests a protocol on the identification of giftedness and talent which ceases to consider an single cut-off point, analyzing instead more rigorously each child's ability profile. Castelló uses the terminology of "single talent", "multiple talent", "complex 
talent" and "conglomerate talent" to refer to the number of areas of strength and the links among them. This is one of the most widespread giftedness and talent identification protocols in Spain and have been tested empirically in different works (Ferrandiz, Prieto, Fernandez, Ferrando, \& Badía, 2010; Ferrando, 2006; Sanchez López, 2006), corroborating that finding that students' cognitive complexity is variable, depending on their profile.

The theoretical typology put forward by Betts and Neilhart (1998) tries to move beyond the mere classification in terms of cognitive abilities and includes in its proposal the individuals' non-cognitive and emotional characteristics. In their work, taking their practitioner experience and based on the literature review, they established seven types of giftedness profiles which are useful for educational counselling; these types are: (1) the successful, (2) the "challenging", (3) the underground, (4) the dropout, (5) the double-labelled, and (6) the autonomous learner. However, this proposal has not been studied at an empirical level.

In the research undertaken by Guskin, Peng and MajdJabbari (1988), authors try to find the different types of gifted students by asking teachers. To do so, the conceptions of 111 training teachers and 79 graduate teachers were analyzed. The participants ordered a number of abilities according to the similarity between them. By means of the different cluster analyses, five categories of giftedness were found: (1) the analytical or cognitive ability, (2) personality and social abilities, (3) creative arts, (4) motor abilities, and (5) verbal abilities.

The research group on high skills of Murcia University has published a study where high skilled students' profiles are analyzed (Hernández-Torrano, Prieto, Ferrándiz, Bermejo, \& Sáinz, 2013). A total of 563 secondary education students labelled as gifted or talented by their teachers participated. These students performed different tests which encompassed psychometric intelligence, divergent thinking, and their multiple intelligences and emotional intelligence as perceived by their teachers. Using a methodology of cluster analysis two main groups of students were found: (1) Those whom scored higher in creative or divergent thinking tests, and (2) those who scored lower in said tests. Within the group of the most creative students, two subgroups were found in turn: (a) those who scored really high in all the tests (cognitive, emotional intelligence and creativity), and (b), those who scored considerably lower than the rest of their classmates in almost all the areas. Within the group of the least creative students, three subgroups were found in turn: (a) students labelled high skilled by their teachers, but whose performance was inferior to that of their classmates (cognitive psychomotor tests and creativity tests); (b) students who scored low in all the tests (compared to other students labelled gifted/talented), and (c) a group of students who excelled significantly at cognitive tasks measured by intelligence tests, but who were not perceived as high skilled students by their teachers.
Robert Sternberg, for his part, avoids using the word typology and opts for the use of "patterns of giftedness", referring to the non-static nature of these patterns (unique combinations of abilities) and to how an individual does not solely belong to one or another category (Sternberg, 2000). The consideration of these patterns or profiles depart from his theory of Triarchic intelligence (Sternberg, 1985, 1997), and suggested in the work "Patterns of Giftedness: A Triarchic Analysis" (2000), in which he identifies seven patterns of strengths and weaknesses in high skilled students. These profiles, as Sternberg himself affirms, are rather loose in the sense that it is probable that they may not be found clearly and that they stem from the combination of strong and weak points of the three types of intelligence that he identified: analytical, creative and practical intelligence. Following a brief description of the seven patterns is offered:

The Analyst: it is inherent to individuals with high analytical skills, but not as outstanding in other areas. They do reasonably well in the academic context. However, these individuals are not particularly creative nor do they usually make creative contributions during adulthood, as it happens in other giftedness profiles.

The Creator: they show a great display of creative skills, but not analytical or practical. They are individuals who excel at generating ideas, yet not at analyzing them or putting them into practice.

The Practitioner: Stands out in abilities linked to practical intelligence, but lack in creative or analytical skills. They are persuasive and, quite often, amusing individuals, but their thinking is less reflective.

The Analytical-Creator: beats the creator in the sense that they are not only good at generating quality, innovative ideas, but also at appraising them and understanding their value. These individuals have a great potential in contributing to their scope of work, due to their ability to criticize their own ideas.

The Analytical-Practitioner: shows both skills related to analytical and practical intelligence; therefore, they are more capable of discerning between the different ideas they propose. This is the kind of giftedness more easily observable in the academic or school context. They are people with great academic intelligence and, besides, they know how to turn this cognitive ability into success. They tend to work in different jobs and can be successful in a conventional manner, but they do not normally make significant contributions to society as a whole.

The Creative-Practitioner: Their forte is creative and practical skills, but not analytical. These individuals have the ability to create ideas and persuade others about the value of these, be they reasonably well expressed or not. Hence, while the practitioner can be good at selling others' ideas, the creative-practitioner could be efficient in selling his/her own ideas (no matter whether these are worth or not). The resulting type is someone effective in convincing others to follow 
ideas not necessarily promising or for which they may not be ready.

The Consummate-Balancer: it is the type of talent where analytical, creative and practical skills are extremely well developed. These individuals are able to apply any or all of the three abilities as needed and, therefore, are in the best position to make valuable contributions to society.

Not until 2011, does Sternberg have the opportunity to prove empirically the existence of these patterns or profiles of giftedness (Kornilov et al., 2011). In this very study, and using a sample of 426 of 4 th, 5th and 6th grade students who were tested with the Aurora Battery as a measurement of successful intelligence abilities. The Q-factor analysis technique was employed to group students according to their similarities. As the Q-factor technique is ideal for small samples, the analytically gifted, creatively gifted and practically gifted (students with I.Q. higher than 120 in the specified intelligence) were analyzed separately, and different analyses were performed on each of those sub-samples. In total, 10 patterns of the combinations of successful intelligence abilities were found in Sternberg's study ( 2 for the analytically gifted, 4 for the creatively gifted and 4 for the practically gifted). In the groupings laid out, some patterns were repeated. In this regard, patterns 4, 6 and 8 corresponded to the consummate balance profile, whereas patterns 5 and 7 corresponded to the analytical-practical profile. It should be highlighted that the patterns found were rather vague, since the profiles defined by Sternberg (2000) did not match completely those of the participants in the study. In fact, the practitioner profile (lacking in creativity and analytical intelligence) were not found in that study (Kornilov et al., 2011).

The aim of the present work is to study the giftedness patterns or profiles suggested by Sternberg (2000). Under this approach, in order to comprehend giftedness, we should pay attention to both intelligence types and also to the patterns of those intelligences combined. According to the taxonomy put forward by Sternberg, it is expected to find 7 types of patterns (the analyst, the creator, the practitioner, the analytical-creator, the analytical-practitioner, the creativepractitioner and the consummate balancer: analyticalpractical-creative).

As it has been exposed, this objective had already been set by Sternberg (Kornilov et al., 2011) using the Q-factor technique so as to study groups of individuals who resembled in their answers. This technique makes it possible to use few individuals to study the communality between variables (Van Exel \& Graaf, 2005) and is especially appropriate for extensive studies of small samples of persons of interest. However, due to the rather reduced sample that this type of analysis allows, as Van Exel \& Graaf (2005) point out there is some concern about the reliability of the results in terms of replicability: will identical results (patterns of response) be found using different samples?

\section{Method}

\section{Participants}

In this study, a total of 431 students aged 8-15 ( $M=$ $10.5 ; D T=1.71), 44 \%$ of them boys, have participated. These students attended different schools of the Region of Murcia (both public and partially-funded). They were studying 3rd, 4th, 5th and 6th year of Primary Education as well as 1st and 2nd year of ESO (Compulsory Secondary Education). The selection of the sample of participants was made by means of an incidental sampling. Table 1 shows the distribution of participants, sorted by gender and academic year.

Table 1. Distribution of participants by gender and grade.

\begin{tabular}{lccccccc}
\hline & 3RD & 4TH & 5TH & 6TH & 1ST & 2ND & \multirow{2}{*}{ Total } \\
& P.E. & P.E. & P.E. & P.E. & C.S.E. & C.S.E. & \\
\hline Boys & 38 & 31 & 44 & 44 & 19 & 16 & 192 \\
Girls & 37 & 41 & 46 & 48 & 33 & 25 & 230 \\
Total & 75 & 72 & 90 & 92 & 52 & 41 & $422 *$ \\
\hline
\end{tabular}

P.E.: Primary Education; CSE: Compulsory Secondary Education

* Note: 9 students did not indicate their gender, and it could be not inferred by their names.

\section{Instrument}

The Aurora-a Battery was used (Chart, Grigorenko, \& Sternberg, 2008), which aims is to assess and recognize different abilities (analytical, practical, and creative) on different types of representation or domains (figurative, numerical and verbal content). The 17 tasks - which measure the three types of intelligence in the three types of representationhave been utilized. Table 2 compiles the activities. This battery has been used with Spanish samples, proving to be a good instrument for gifted identification (Prieto, Ferrándiz, Ferrando, \& Bermejo, 2015).

The Analytical or Academic Intelligence (AI) tasks evaluate the ability to solve problems, pass judgment on the quality of the ideas or take decisions in the academic context. The scoring criteria for this multiple option items are either right or wrong.

The Practical Intelligence (PI) tasks are meant to assess the ability to apply knowledge to the resolution of everyday problems. They assess the ability to solve problems, pass judgment on the quality of the ideas or take decisions in the real world.

The Creative Intelligence (CI) tasks are used to evaluate the ability to find original and non-conventional solutions to situations and problems occurring in everyday life. They value the use of the necessary abilities to create, imagine, invent, discover, speculate and formulate hypotheses. Except for the figurative language task, all others are open-ended questions, and they were assessed by two ratters using a 0-4 scale for the criteria facilitated by Sterberg's collaborators. 
Table 2. Aurora-a grid: the Aurora subtests grouped by target ability and domain

\begin{tabular}{|c|c|c|c|}
\hline & Analytical & Creative & Practical \\
\hline \multirow{4}{*}{$\begin{array}{l}\text { Figurative } \\
\text { (visual / spatial) }\end{array}$} & Shapes (Abstract Tangrams) & Book Covers & Paper Cutting \\
\hline & $\begin{array}{l}\text { Complete shapes with missing pieces. } \\
\text { (10 items) (MC). }\end{array}$ & $\begin{array}{l}\text { Interpret an abstract picture and } \\
\text { invent a story to accompany it. } \\
(5 \text { items })(\mathrm{OE})\end{array}$ & $\begin{array}{l}\text { Identify the proper unfolded version of a } \\
\text { cut piece of paper } \\
\text { (10 items) (OM) }\end{array}$ \\
\hline & Floating Boats & Multiple Uses & Toy Shadows \\
\hline & $\begin{array}{l}\text { Identify matching patterns among connect- } \\
\text { ed boats. } \\
\text { ( } 5 \text { items) (MC) }\end{array}$ & $\begin{array}{l}\text { Devise three new uses for each of } \\
\text { several household items. } \\
\text { (5 items) (OE) }\end{array}$ & $\begin{array}{l}\text { Identify the shadow that will be cast by a } \\
\text { toy in a specific orientation. } \\
\text { (8 items) (MC) }\end{array}$ \\
\hline \multirow{4}{*}{$\begin{array}{l}\text { Words } \\
\text { (verbal) }\end{array}$} & Words That Sound the Same (Homophone) & (Inanimate) Conversations & (Silly) Headlines \\
\hline & $\begin{array}{l}\text { Blank sentence with two missing words us- } \\
\text { ing homonyms. } \\
(20 \text { items })(\mathrm{RW})\end{array}$ & $\begin{array}{l}\text { Create dialogues between objects } \\
\text { that cannot typically talk. } \\
(10 \text { items })(\mathrm{OE})\end{array}$ & $\begin{array}{l}\text { Identify and explain an alternative "silly" } \\
\text { meaning of actual headlines. } \\
\text { (11 items) (RW) }\end{array}$ \\
\hline & (Limited) Metaphors & Interesting (Figurative) Language & Decisions \\
\hline & $\begin{array}{l}\text { Explain how two somewhat unrelated things } \\
\text { are alike. } \\
\text { (10 items) (OE) }\end{array}$ & $\begin{array}{l}\text { Interpret what sentence logically } \\
\text { comes next after one containing } \\
\text { figurative language. } \\
\text { (12 items) (MC) }\end{array}$ & $\begin{array}{l}\text { List elements given in a scenario on either } \\
\text { "goo" or "bad" side of a list in order to } \\
\text { make a decision. } \\
\text { (3 items) (RW) }\end{array}$ \\
\hline \multirow{4}{*}{$\begin{array}{l}\text { Numbers } \\
\text { (numerical) }\end{array}$} & Number cards & \multirow{4}{*}{$\begin{array}{l}\text { Number Talk } \\
\text { Imagine reasons for various de- } \\
\text { - scribed social interactions be- } \\
\text { tween numbers. } \\
\text { (7 items) (OE) }\end{array}$} & Maps (Logistics Mapping) \\
\hline & $\begin{array}{l}\text { Find the single-digit number that letters rep- } \\
\text { resent in equations. } \\
\text { (5 items) (RW) }\end{array}$ & & $\begin{array}{l}\text { Trace the best carpooling routes to take be- } \\
\text { tween friends' houses and destinations. } \\
\text { (10 items) (RW) }\end{array}$ \\
\hline & Story Problems (Algebra) & & Money (Exchange) \\
\hline & $\begin{array}{l}\text { Devise ways to solve logical and math prob- } \\
\text { lems with two or more missing variables. } \\
\text { (5 items) (RW) }\end{array}$ & & $\begin{array}{l}\text { Divide complicated "bills" appropriately be- } \\
\text { tween friends. } \\
\text { (5 items) (RW) }\end{array}$ \\
\hline
\end{tabular}

Note. MC: Multiple Choice; OE: Open-Ended items that need to be scored by an individual using a rating scale; RW: answers are either Right o Wrong (Prieto, Ferrándiz, Ferrando \& Bermejo, 2015).

\section{Procedure}

The evaluation tasks carried out were administered collectively inside the classroom (group-classroom). Two sessions with an approximate duration of three hours were used for such purpose, during school time. The application of these instruments has been done by Pedagogy, psychology and Psychopedagogy graduates. The tests correction was carried out following the instructions of Yale University's work team. Creativity was appraised by two judges, who had been trained so as to reach a reasonable level of agreement in their marks. During this phase, it was observed that the variable "adequacy of the answer" overlapped with "creativity of the answer"; therefore, the criterion was modified in such a way that a non-adequate answer would score a 0 in creativity. Besides, it was considered that variables such as handwriting or the order of answers could affect the evaluator's judgment, and so, every answer was transferred to an EXCEL spreadsheet, which was assessed individually, with no attention paid to whom had given such answer.

Once the scores were obtained, they were transferred to a data sheet utilizing the IBM SPSS V. 20 (IBM, 2011) software.

In the study carried out by Kornilov et al (2011) the scores in the three types of intelligence, measured by the Aurora Battery were transformed into IQ scores. That is, the mean of the scoring was 100 and the standard deviation 15.
This transformation was conducted for the whole sample, independently of their ages. This could be questionable, as it was expected that older children would obtain higher marks if compared to younger ones. For that reason, in our study, the transformation in IQ scores has been done for each academic year the participant students belonged to.

As it has been mentioned before, in order to study highskill profiles by means of the Aurora Battery, a Q-factor analysis technique has been utilized. With the purpose of studying high-abilities profiles, those students with analytical, creative and/or practical talent were selected. To do so, it was taken as a cut-off point that students scored equal to or above IQ= 120 in each of the intelligences (analytical, creative and practical), something which guaranteed an above the average standard deviation.

The way the Q-factor analyses were performed was by transposing data matrices, in such a way that individuals are turned into variables. A factor analysis exploring the principal components with varimax rotation was carried out (as the correlation between the factors extracted was $r<.001$ ).

In order to decide which pattern of response was more characteristic of each individual, taking into account the loading absolute value, factor loading matrices were used. Since factor loading values can be either positive or negative, each factor represents two potential profiles: a main profile and its opposite. 
To decide which main component saturates more an individual, it was decided to opt for the factor which had the highest loading, which could be calculated by means of a simple subtraction between the loads of each factor. However, as there were negative loads, it was concluded that, in order to suppress the loads mark, the best solution was squaring them. Therefore, the resulting formula was: (Component I)^2 - (Component II $)^{\wedge} 2$. If the result of the equation was positive, the individual would be assigned to the component I, if it was negative, he/she would be assigned to the component II. Since the factor loading values can be positive or negative, each component represents two potential profiles: a main profile and its opposite. For the main profile we have used the abbreviation $(+)$ and for its opposite (-).

\section{Results}

\section{Descriptive statistics and correlations between vari-} ables

Firstly, we will show the descriptive statistics of each one of the students (Table 3). In the raw scores, it can be observed that there are differences regarding the mean scoring of the students sorted by academic year. There seems to be an increase linked to the academic year, peaking with 6th year of Primary Education students. Besides, it could be observed that the scores in the different intelligences had different scoring ranges; for this reason, the scores were trans- formed to IQ marks $(M=100, S D=15)$ for each of the academic years.

Next, the correlations between the scores in analytical, creative and practical intelligence were estimated. It could be seen that the correlation between those range from $\mathrm{r}=.383$; $\mathrm{p}<.01$ (between practical and creative intelligence) and $r=$ $.594, p<.01$ (for the relation between analytical and creative). The correlation between creative intelligence and analytical intelligence was $r=.484, p<.01$.

\section{High abilities' profiles}

First, students with high analytical talent were selected (IQ $\geq 120$ ), adding up to 27 students. When these 27 students underwent a factor analysis (Q-factor previously described in the procedure), two main components with eigenvalues above 1 which explained $100 \%$ of the variance appeared. Though each component is likely to represent two profiles (the positive and its opposite), in this very analysis three profiles (two with positive sign and one negative) were found in total.

The first component was represented by 15 students, characterized by having high analytical and practical intelligence, but moderate creative intelligence and which we could call profile A.I. (+). The second component found includes students with high levels of analytical and creative intelligence $(\geq 120)$, which we could refer to as A.II $(+)$. This component included a student with an opposite profile A.II (-), who showed great analytical intelligence and very high practical intelligence (see Table 4 and Figure 1).

Table 3. Descriptive statistics on Aurora scores by course and for the whole sample.

\begin{tabular}{|c|c|c|c|c|c|c|c|c|c|c|c|c|}
\hline & \multicolumn{4}{|c|}{ Analytical Int. Direct Score } & \multicolumn{4}{|c|}{ Practical Int. Direct Score } & \multicolumn{4}{|c|}{ Creative Int. Direct Score } \\
\hline & Min. & Max. & $M$ & $S D$ & Min. & Max. & $M$ & $S D$ & Min. & Max. & $M$ & $S D$ \\
\hline 3rd PE. $(n=75)$ & 28.86 & 47.44 & 40.25 & 6.37 & 11.17 & 21.53 & 17.47 & 3.76 & 41.17 & 98.17 & 76.18 & 11.17 \\
\hline 4th PE $(\mathrm{n}=72)$ & 15.00 & 59.76 & 34.51 & 9.18 & 2.00 & 27.00 & 13.16 & 5.10 & 47.31 & 113.67 & 79.97 & 13.05 \\
\hline 5th PE $(\mathrm{n}=90)$ & 18.36 & 58.19 & 39.44 & 8.85 & 7.00 & 29.00 & 17.41 & 5.61 & 50.83 & 116.17 & 84.90 & 14.42 \\
\hline 6th PE $(\mathrm{n}=90)$ & 20.00 & 68.00 & 45.04 & 10.34 & 6.00 & 31.00 & 19.78 & 6.22 & 60.17 & 116.72 & 89.59 & 14.47 \\
\hline 1st $\operatorname{CSE}(\mathrm{n}=52)$ & 14.00 & 65.19 & 41.91 & 10.07 & 4.00 & 28.00 & 20.31 & 5.31 & 46.83 & 109.33 & 85.06 & 13.65 \\
\hline 2nd CSE $(n=50)$ & 27.12 & 61.00 & 45.68 & 8.83 & 9.00 & 32.00 & 21.50 & 5.19 & 46.51 & 111.17 & 87.27 & 15.34 \\
\hline TOTAL $(\mathrm{N}=431)$ & 2.00 & 32.00 & 18.04 & 5.88 & 14.00 & 68.00 & 40.97 & 9.72 & 41.17 & 116.72 & 83.85 & 14.40 \\
\hline
\end{tabular}

PE: Primary Education; CSE: Compulsory Secondary Education

Table 4. Resume of students' profiles found.

\begin{tabular}{|c|c|c|c|c|c|c|c|c|c|}
\hline & \multirow[b]{2}{*}{ Extracted Components (\% a.c.) } & \multirow[b]{2}{*}{ Profile name } & \multirow[b]{2}{*}{$N$} & \multicolumn{2}{|c|}{ Analytical IQ } & \multicolumn{2}{|c|}{ Practical IQ } & \multicolumn{2}{|c|}{ Creative IQ } \\
\hline & & & & $M$ & $D T$ & $M$ & $D T$ & $M$ & $D T$ \\
\hline \multirow{4}{*}{ Group of Analytical IQ > 120} & Comp. I & A.I $(+)$ & 15 & 127.60 & 5.99 & 120.71 & 8.19 & 110.04 & 12.55 \\
\hline & (55.34\% a.c.) & A.I $(-)$ & 0 & & & & & & \\
\hline & Comp. II & A.II $(+)$ & 11 & 125.55 & 4.00 & 106.19 & 10.92 & 121.33 & 10.54 \\
\hline & $(44.65 \%$ a.c. $)$ & A.II(-) & 1 & 121,77 & & 140.69 & & 102.91 & \\
\hline \multirow{4}{*}{ Group of Practical IQ >120 } & Comp. I. & P.I $(+)$ & 20 & 111.18 & 6,83 & 125.16 & 4.62 & 104.23 & 8.56 \\
\hline & (66.095\% a.c.) & P.I $(-)$ & 0 & & & & & & \\
\hline & \multirow{2}{*}{ Comp. II (33.905\% a.c.) } & P.II $(+)$ & 7 & 131.10 & 5.71 & 126.63 & 6.08 & 113.17 & 17.08 \\
\hline & & P.II(-) & 6 & 109.92 & 8.31 & 124.50 & 5.07 & 124.88 & 6.74 \\
\hline \multirow{4}{*}{ Group of Creative IQ > 120} & Comp. I & C.I $(+)$ & 16 & 104.26 & 11.06 & 111.35 & 12.53 & 124.75 & 3.74 \\
\hline & (69.76\% a.c.) & C.I $(-)$ & 3 & 135.35 & 5.20 & 131.93 & 5.41 & 124.67 & 2.79 \\
\hline & Comp. II & C.II $(+)$ & 14 & 119.59 & 8.03 & 107.30 & 8.48 & 125.92 & 4.96 \\
\hline & (30.23\% a.c.) & C.II $(-)$ & 1 & 118.81 & & 122.23 & & 120.82 & \\
\hline
\end{tabular}

Comp.: Principal component obtained; a.c.: accounted variance; $N$ : number of students that show that profile 
Secondly, the analysis for practical intelligence was performed: students with IQ equal to or greater than 120 in practical intelligence were selected $(n=33)$. Two main components which explained $100 \%$ of the variance were found, resulting in three different profile types in total: profile P.I $(+)$, characterized by showing high scores in practical intelligence, but moderate in analytical and creative, profile P.II $(+)$, which seemed to show a balance between practical and analytical intelligence, but whose weakest link is creative intelligence, and profile P.II (-), whose weak link is analytical intelligence.
Thirdly, the creatively talented were selected $(n=34)$ and four creative talent profiles were found. Profile C.I. $(+)$ was characterized by featuring high creative intelligence and moderate practical and analytical intelligences. Profile C.I (-) shows a balance between the three types of intelligence. Profile C.II $(+)$ is distinguished by its high creative intelligence, while it shows moderate practical intelligence. Profile C.II (-) was only represented by student who excelled at practical and creative intelligence (Table 4 and Figure 1).

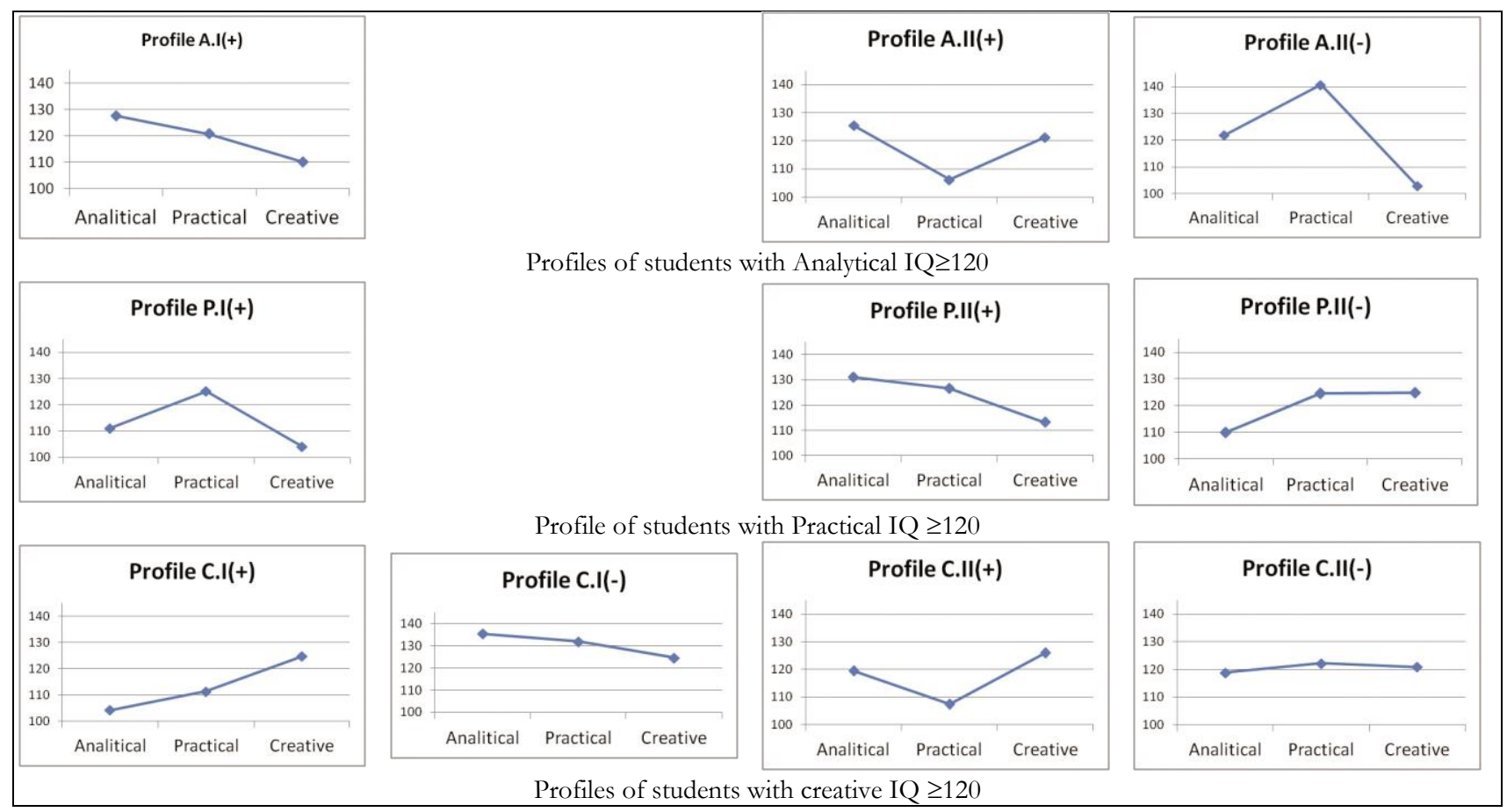

Figure 1. Graphs of mean scores on Analytical, Practical and Creative Intelligences of the eight students' profile found

In the annex (Tables 5, 6 and 7), the factor loading of each variable (cases) in the different components extracted for each of the intelligences (analytical, practical and creative), can be consulted.

\section{Discussion and conclusions}

The present work has aimed to delve deeper into the study of high ability (giftedness and talent) under the Successful Intelligence model (Sternberg, 1997, 2000). While we know that high ability is mainly defined by the cognitive profile and by the combination of strengths and weaknesses, not many empirical studies have been carried out so as to identify those profiles among high-skilled students.

The theoretical model of Intelligence from which we have departed is comprehensive enough so as to enable our study not to be restricted to the analysis of the characteristics of intelligence assessed at school and already considered by the traditional models on the study of high ability (Cox, 1926; Galton, 1869; Terman, 1925), but rather move beyond, steering the approach towards the study of how the cognitive resources that high-skilled students use are handled.

Sternberg and his collaborators had already corroborated the existence of different profiles in their work of the year 2011 (Kornilov et al., 2011); our enquiry was, hence, the following: would it be possible to identify the same profiles in Spanish students? In our work we have been able to find a correspondence between the theoretical profiles defined by Sternberg and the profiles found in our data.

The only profile that could not be verified by the data is the pure analytical. Instead, the pure creative profile was found in 16 students $(\mathrm{C} . \mathrm{I}(+))$, with great mastery of the ability to suggest original and unusual ideas, while the use they 
make of analytical and practical intelligence resources is more moderate.

The pure practical was found in 20 students (P.I.(+)).who show great capacity to apply tacit knowledge to the solution of everyday problems; their abilities related to abstract reasoning and creativity are, however, used with a lower level of dexterity

The combinations of analytical-creative was found in 25 students (profiles A.II $(+)$ and C.II $(+)$ ). It includes students with high abilities aimed at problem-solving, analyzing ideas profoundly and making the appropriate decisions in the solution of academic problems; they stand out, besides, in their ability to suggest original and unusual ideas.

The analytical-practical profile was found in 23 students (A.I(+), A.II(-) and P.II(+)). Students who use with great dexterity resources to solve problems, judge ideas and make decisions within the academic context and also in everyday life. However, their handling of resources related to creative intelligence is rather modest.

Six students presented a creative-practical profile (P.II()). They stand out in their handling of creative and practical skills. This student shows as well great capacity to create ideas and persuade people about the value of these.

Finally four students show a consummated balanced profile of giftedness with high scores on the three intelligences: analytical, practical and creative (C.I(-) and C.II(-)). These students show great dexterity in applying those abilities as they are needed to make significant contributions.

The profiles found so far corroborate Sternberg's proposal (2000). However, between the profiles here found and those found by Sternberg's team, there are noticeable differences. For instance, in Kornilov et al's work (2011), up to 10 patterns or profiles of different abilities were found (though patterns 6 and 8 were repeated). And, even with that abundance of profiles, the perfect practitioner profile could not be found, a profile which we have been able to find in our study.

In Kornilov et al. (2011), it is implied that the scores in the three types of intelligence were transformed into IQ scores $(M=100, S D=15)$, without taking into consideration the academic year the students were in, which could imply that students with higher IQ were precisely older students (as the variable age and/or academic year was not controlled). This could explain the variety of patterns and profiles found by Sternberg's team and why we have not found such diversity.

\section{References}

Betts, G. T., \& Neihart, M. (1988). Profiles of the gifted and talented. Gifted child quarterly, 32(2), 248-253.

Castelló, A., \& de Batlle, C. (1998). Aspectos teóricos e instrumentales en la identificación del alumno superdotado y talentoso: propuesta de un protocolo. Faisca: Revista de altas capacidades, 6, 26-66

Chart, H., Grigorenko, E.L. \& Sternberg, R.J. (2008). Identification: The Aurora Battery. In J. A. Plucker \& C.M. Callahan (Eds.), Critical issues and practices in gifted education (pp. 281-301). Waco, TX: Prufrock.
The present work represents a breakthrough in the understanding of high-skilled students. Notwithstanding, in order to ratify the profiles found, contrast studies on different people but with similar socio-cultural backgrounds should be carried out, so as to value the replicability of our results.

We also need to consider that these profiles shed light on the different shapes that talent can take. But some deepening on the meaning of those profiles is yet to be done. The theory could be applied into different specific talents, as the work by Sak (2008) suggested. Sak, who studied the mathematical talent, proposed and tested three mathematical minds based on Sternberg theory: "expert analyst, who is competent both in domain knowledge and in analysis; creative expert, who is a good intuitive free thinker and has remarkable domain knowledge. By the same token, the interaction of analysis and creativity gives birth to a creative analyst, who has both good, logical judgment and an a priori synthetic judgment. Finally, the interaction of all brings into being a master, who demonstrates remarkable analytical ability, domain knowledge, and creative productivity and who, no doubt, should be very rare" (Sak, 2008, p. 57).

Other future lines of research are necessary. For example, increasing the number of variables included in the profiles studied and don't reduce them to the areas related to the cognitive skills existing in the three types of intelligence. For instance, while Sternberg (2000) suggests in his work personality characteristics and even encourages foreseeing different experiences corresponding to each profile, it is true that we should corroborate that information in forthcoming empirical research, to test if the reasoning applied on the seven profiles of triarchic intelligence is proven true.

In addition, the present research should be completed following a longitudinal study to corroborate the stability/dynamic of the gifted patters found. In this sense the research conducted by Cho, Ahm, Han and Park (2008) does give us an insight about different evolution patterns of giftedness. In their retrospective research clustering gifted students depending on different cognitive and non-cognitive variables, they found four patterns: the $\mathrm{t}$ of them did not achieve as high as their early promise pre-the Full-bloomer, the Good-achiever, the Fade-away, and the Late-bloomer.

Acknowledgements - This article has been produced with the financial support of both: a) Seneca Foundation-Regional Science and Technology Agency (Murcia, Spain) (Ref.: 11896/PHCS/09); b) Spanish Ministry of Science and Technology (EDU2011016370).

Cho, S., Ahn, D., Han, S., \& Park, H. (2008). Academic developmental patterns of the Korean gifted during the 18 years after identification. Personality and Individual Differences, 45(8), 784-789.

Cox, C. (1926). Genetic studies of genius, the early mental traitr of 300 geniuses. Stanford, CA: Stanford University Press.

Ericsson, K. A. (2006). The influence of experience and deliberate practice on the development of superior expert performance. The Cambridge bandbook of expertise and expert performance, 683-703. 
Ferrandiz, C., Prieto, M.D., Fernandez, M.C.; Ferrando, M., Badía, M. (2010) Modelo de identificación de alumnos con altas habilidades de Educación Secundaria. Revista electrónica interuniversitaria de formación del profesorado, 13(1), 63-74.

Ferrando M. (2006). Creatividad e Inteligencia Emocional. Un estudio empirico en alumnos con altas habilidades. Tesis Doctoral Universidad de Murcia.

Gagne, F. (2015). From genes to talent: the DMGT/CMTD perspective. Revista de Educacion, 368, 12-39.

Galton. F. (1869). Hereditary genius: An Inquiry into Its Laws and Consequences. London: Macmillan.

Gardner, H. (1983/1995). Frames of Mind: The Theory of Multiple Intelligences. New York: Basic. (Trad. Castellano: Inteligencias múltiples: La teoría en la práctica. Barcelona: Paidós).

Gardner, H., Feldman, D. y Krechevsky, M. (1998). Project Spectrum: Building on Children's Strengths: The Experience of Project Spectrum. N.Y.: Teachers College Press.

Guskin, S. L., Peng, C-Y. J. \& Majd-Jabbari, M. (1988). Teachers'perceptions of giftedness. Gifted Child Quarterly, 32, 216-221.

Hernandez, D., Ferrandiz, C., Prieto, M.D., Sáinz, M., Ferrando, M. y Bermejo, R. (2011). Inteligencia exitosa y atención a la diversidad del alumno de alta habilidad. Aula Abierta, 39(2), 103-112.

Hernández, D., Prieto, M. D., Ferrándiz, C., Bermejo, R., \& Sáinz, M. (2013). Characteristics leading teachers to nominate secondary students as gifted in Spain. Gifted Child Quarterly, 57(3), 181-196.

IBM Corp. (2011). IBM SPSS Statistics for Windows, Version 20.0. Armonk, NY: IBM Corp.

Kornilov, S. A., Tan, M., Elliott, J. G., Sternberg, R. J., \& Grigorenko, E. L. (2011). Gifted identification with Aurora: Widening the spotlight. Journal of Psychoeducational Assessment, 30(I) 117-134.

Marland, S. P. (1972). Education of the Giftes and Talented. Report to the Subcommittee on Education. Committee on Labor and Public Welfare. U. S. Senate. Washington, D.C.: Gouvernement Printting Office.
Prieto, M. D., Ferrándiz C., \& Ballester, P. (2001). Evaluación de la competencia cognitiva desde la teoría de las Inteligencias Múltiples. Enseñanza. 19, 91-111.

Prieto, M.D.; Ferrándiz, C.; Ferrando, M. \& Bermejo, M.R. (2015). Aurora Battery: A new assessment of successful intelligence, Revista Educación. Ministerio de Educación, Cultura y Deportes, 368, 132-157.

Renzulli, J. S. (2003). The three-ring conception of giftedness: Its implications for understanding the nature of innovation. En Larisa V. Shavinina (Ed.), The international handbook on innovation (pp.79-96). Elsevier Science: Oxford, UK Springer.

Sak, U. (2008). Test of the three-mathematical minds (M3) for the identification of mathematically gifted students. Roeper Review, 31(1), 53-67.

Sánchez López, C. (2006). Configuración cognitivo-emocional en alumnos de altas habilidades. Tesis Doctoral Universidad de Murcia.

Sternberg, R. J. (1985). Beyond IQ: a triarchic theory of human intelligence. New York: Cambridge University Press.

Sternberg, R. J. (1997). Successful intelligence. New York: Plume.

Sternberg, R. J. (2000). Patterns of giftedness: A triarchic analysis. Roeper Review, 22(4), 231-235.

Terman, L. M. (1925). Genetic studies of genius. Mental and physical traits of a thousand gifted children. Palo Alto, CA, US: Stanford University Press.

Thompson, B. (2010). Q-technique factor analysis as a vehicle to intensively study especially interesting people. In B. Thompson \& R. Subotnik (Eds.), Methodologies for conducting research on giftedness (pp. 33-52). Washington, DC: APA.

Van Exel N. J. A. \& G de Graaf (2005). Q methodology: A sneak preview [available from www.jobvanexel.nl].

(Article received: 04-02-2015; revised: 13-01-2016; accepted: 01-02-2016) 


\section{Annex}

Table 5. Factorial loadings of Q-Factor Analysis for students with Analytical IQ $>120$

\begin{tabular}{|c|c|c|c|c|}
\hline Case & Loadings in comp. I & Loadings in comp. II & $(\operatorname{comp} I) 2-(\operatorname{comp} I I) 2$ & Profile \\
\hline$\overline{\text { CASE_27 }}$ & 1 & 0.08 & 0.99 & A.I $(+)$ \\
\hline CASE_46 & 0.98 & -0.19 & 0.93 & A.I $(+)$ \\
\hline CASE_67 & 0.99 & 0.17 & 0.94 & A.I $(+)$ \\
\hline CASE_92 & 0.97 & -0.25 & 0.88 & A.I $(+)$ \\
\hline CASE_143 & 0.99 & 0.17 & 0.94 & A.I $(+)$ \\
\hline CASE_258 & 0.97 & 0.26 & 0.87 & A.I $(+)$ \\
\hline CASE_292 & 1 & -0.03 & 1 & A.I $(+)$ \\
\hline CASE_319 & 0.9 & -0.45 & 0.6 & A.I $(+)$ \\
\hline CASE_323 & 0.96 & -0.27 & 0.86 & A.I $(+)$ \\
\hline CASE_330 & 0.96 & 0.28 & 0.85 & A.I $(+)$ \\
\hline CASE_373 & 1 & -0.07 & 0.99 & A.I $(+)$ \\
\hline CASE_406 & 0.79 & -0.62 & 0.23 & A.I $(+)$ \\
\hline CASE_419 & 0.91 & -0.42 & 0.65 & A.I $(+)$ \\
\hline CASE_429 & 0.9 & 0.44 & 0.61 & A.I $(+)$ \\
\hline CASE_434 & 0.85 & 0.53 & 0.43 & A.I $(+)$ \\
\hline CASE_90 & 0.52 & -0.85 & -0.45 & A.II(-) \\
\hline CASE_78 & -0.32 & 0.95 & -0.79 & A.II $(+)$ \\
\hline CASE_80 & -0.3 & 0.95 & -0.82 & A.II $(+)$ \\
\hline CASE_98 & -0.01 & 1 & -1 & A.II $(+)$ \\
\hline CASE_158 & 0.68 & 0.73 & -0.07 & A.II $(+)$ \\
\hline CASE_242 & -0.27 & 0.96 & -0.85 & A.II $(+)$ \\
\hline CASE_252 & 0.63 & 0.78 & -0.21 & A.II $(+)$ \\
\hline CASE_287 & 0.15 & 0.99 & -0.96 & A.II $(+)$ \\
\hline CASE_291 & 0.15 & 0.99 & -0.96 & A.II $(+)$ \\
\hline CASE_294 & 0.26 & 0.97 & -0.86 & A.II $(+)$ \\
\hline CASE_425 & 0.09 & 1 & -0.98 & A.II $(+)$ \\
\hline CASE_428 & 0.14 & 0.99 & -0.96 & A.II(+) \\
\hline
\end{tabular}

The loadings come from the rotated matrix (varimax) 
Table 6. Factorial loadings of Q-Factor Analysis for students with Practical IQ $>120$

\begin{tabular}{|c|c|c|c|c|}
\hline Case & Loadings in comp. I & Loadings in comp. II & (comp I)2 - (comp II)2 & Profile \\
\hline CASE_25 & 1 & -0.08 & 0.99 & P.I(+) \\
\hline CASE_90 & 0.94 & 0.34 & 0.77 & P.I $(+)$ \\
\hline CASE_99 & 0.98 & 0.22 & 0.91 & P.I $(+)$ \\
\hline CASE_167 & 0.98 & -0.2 & 0.92 & P.I $(+)$ \\
\hline CASE_265 & 1 & -0.01 & 1 & P.I $(+)$ \\
\hline CASE_288 & 0.95 & 0.32 & 0.8 & P.I $(+)$ \\
\hline CASE_289 & 0.97 & 0.25 & 0.87 & P.I $(+)$ \\
\hline CASE_297 & 1 & 0.04 & 1 & P.I $(+)$ \\
\hline CASE_331 & 0.88 & 0.48 & 0.53 & P.I $(+)$ \\
\hline CASE_332 & 0.98 & -0.19 & 0.93 & P.I $(+)$ \\
\hline CASE_347 & 0.99 & -0.14 & 0.96 & P.I $(+)$ \\
\hline CASE_365 & 0.97 & 0.26 & 0.86 & P.I $(+)$ \\
\hline CASE_371 & 1 & 0.07 & 0.99 & P.I $(+)$ \\
\hline CASE_406 & 0.77 & 0.64 & 0.17 & P.I $(+)$ \\
\hline CASE_410 & 0.99 & 0.17 & 0.94 & P.I $(+)$ \\
\hline CASE_412 & 0.93 & -0.38 & 0.71 & P.I $(+)$ \\
\hline CASE_432 & 0.98 & 0.22 & 0.9 & P.I $(+)$ \\
\hline CASE_436 & 1 & -0.06 & 0.99 & P.I $(+)$ \\
\hline CASE_437 & 0.96 & 0.28 & 0.84 & P.I $(+)$ \\
\hline CASE_438 & 0.96 & 0.28 & 0.84 & P.I $(+)$ \\
\hline CASE_55 & -0.23 & -0.97 & -0.89 & P.II(-) \\
\hline CASE_88 & 0.61 & -0.79 & -0.26 & P.II(-) \\
\hline CASE_91 & 0.48 & -0.88 & -0.54 & P.II(-) \\
\hline CASE_263 & 0.36 & -0.94 & -0.75 & P.II(-) \\
\hline CASE_326 & -0.12 & -0.99 & -0.97 & P.II(-) \\
\hline CASE_430 & 0.7 & -0.72 & -0.03 & P.II(-) \\
\hline CASE_27 & 0.12 & 0.99 & -0.97 & P.II $(+)$ \\
\hline CASE_92 & 0.44 & 0.9 & -0.62 & P.II $(+)$ \\
\hline CASE_292 & 0.23 & 0.97 & -0.9 & P.II $(+)$ \\
\hline CASE_319 & 0.62 & 0.79 & -0.23 & P.II $(+)$ \\
\hline CASE_323 & 0.46 & 0.89 & -0.58 & P.II $(+)$ \\
\hline CASE_330 & -0.08 & 1 & -0.99 & P.II $(+)$ \\
\hline CASE_419 & 0.59 & 0.81 & -0.3 & P.II $(+)$ \\
\hline
\end{tabular}

The loadings come from the rotated matrix (varimax) 
Table 7. Factorial loadings of Q-Factor Analysis for students with Practical IQ $>120$.

\begin{tabular}{|c|c|c|c|c|}
\hline Case & Loadings in comp. I & Loadings in comp. II & (comp I)2 - (comp II)2 & Profile \\
\hline CASE_92 & -0.95 & -0.32 & 0.8 & C.I(-) \\
\hline CASE_419 & -0.87 & -0.49 & 0.53 & C.I (-) \\
\hline CASE_27 & -1 & 0.01 & 1 & C.I (-) \\
\hline CASE_91 & 0.81 & -0.59 & 0.3 & C.I $(+)$ \\
\hline CASE_89 & 1 & -0.05 & 1 & C.I $(+)$ \\
\hline CASE_81 & 1 & 0.03 & 1 & C.I $(+)$ \\
\hline CASE_73 & 0.98 & 0.18 & 0.94 & C.I $(+)$ \\
\hline CASE_55 & 1 & 0.1 & 0.98 & C.I $(+)$ \\
\hline CASE_45 & 0.94 & 0.35 & 0.75 & C.I $(+)$ \\
\hline CASE_421 & 0.89 & 0.45 & 0.6 & C.I $(+)$ \\
\hline CASE_360 & 0.79 & 0.62 & 0.24 & C.I $(+)$ \\
\hline CASE_359 & 0.99 & 0.17 & 0.94 & C.I $(+)$ \\
\hline CASE_326 & 1 & -0.01 & 1 & C.I $(+)$ \\
\hline CASE_305 & 0.85 & 0.53 & 0.45 & C.I $(+)$ \\
\hline CASE_263 & 0.88 & -0.47 & 0.56 & C.I $(+)$ \\
\hline CASE_198 & 0.88 & 0.48 & 0.53 & C.I $(+)$ \\
\hline CASE_129 & 0.82 & 0.58 & 0.33 & C.I $(+)$ \\
\hline CASE_124 & 0.89 & 0.45 & 0.6 & C.I $(+)$ \\
\hline CASE_104 & 0.78 & 0.63 & 0.2 & C.I $(+)$ \\
\hline CASE_98 & -0.07 & 1 & -0.99 & C.II(-) \\
\hline CASE_425 & -0.17 & 0.99 & -0.94 & C.II(-) \\
\hline CASE_291 & -0.23 & 0.97 & -0.9 & C.II(-) \\
\hline CASE_80 & 0.23 & 0.97 & -0.9 & C.II $(+)$ \\
\hline CASE_78 & 0.25 & 0.97 & -0.87 & C.II $(+)$ \\
\hline CASE_433 & 0.7 & 0.71 & -0.01 & C.II $(+)$ \\
\hline CASE_430 & 0.62 & -0.78 & -0.23 & C.II $(+)$ \\
\hline CASE_402 & 0.32 & 0.95 & -0.8 & C.II $(+)$ \\
\hline CASE_40 & 0.29 & 0.96 & -0.83 & C.II $(+)$ \\
\hline CASE_298 & 0.61 & 0.79 & -0.26 & C.II $(+)$ \\
\hline CASE_280 & 0.59 & 0.81 & -0.31 & C.II $(+)$ \\
\hline CASE_254 & 0.61 & 0.79 & -0.25 & C.II $(+)$ \\
\hline CASE_242 & 0.2 & 0.98 & -0.92 & C.II $(+)$ \\
\hline CASE_213 & 0.34 & 0.94 & -0.76 & C.II $(+)$ \\
\hline CASE_211 & 0.33 & 0.95 & -0.79 & C.II $(+)$ \\
\hline
\end{tabular}

The loadings come from the rotated matrix (varimax) 